\title{
Will fruits and vegetables now be part of the international agenda?
}

Whereas previous Fruits editorials sometimes highlighted the lack of attention paid to fruits amongst crops in the international agenda, it seems that things are currently moving. A key element that illustrates this evolution is the recently published UN report on "The State of Food Insecurity in the World" (http:// www.fao.org/publications/sofi/en).

This report recognizes now that fruits and vegetables are an important component of a healthy diet, referring to the recommendation of the WHO and FAO for a minimum daily intake of $400 \mathrm{~g}$ of fruits and vegetables. Paying attention to the links with health, it indicates that with levels lower than this there may be an increased risk of chronic diseases and that an adequate intake of fruits and vegetables also contributes to the prevention of micronutrient deficiencies.

This report also indicates that, worldwide, the share of cereals, roots and tubers has decreased significantly, whereas the share of fruits and vegetables has increased recognizing the beneficial impact on health and nutrition of such an evolution. However, strong contrasts between regions are reported. Whereas die- tary intakes of fruit and vegetables have grown significantly in Asia, they remain stagnant in sub-Saharan Africa, where the share of dietary energy intake comes in vast majority from cereals, roots and tubers. In this report, it is also interesting to note that, in countries where incomes are growing, the contribution of cereals, roots and tubers to total per capita food supply decreases, whereas the contributions of animal-source foods and of fruits and vegetables increase significantly.

These references to fruits and vegetables in such a key report could be seen as a good signal of an emerging awareness of the international community on the need to integrate them in the general agenda of food security, where the links between agriculture, nutrition and health are even more obvious and necessary. However, it would have been far better if the role of fruit and vegetables would have been part of the key messages of this report, which would have given it much greater visibility.
Dr. Jacky Ganry Scientific Director of Fruits 


\section{Les fruits et légumes vont-ils maintenant intégrer l'ordre du jour international?}

Alors que les éditoriaux de Fruits précédents soulignaient parfois le manque d'attention portée aux fruits sur le plan international, par rapport aux productions agricoles de base, il semble que les choses soient en train de bouger. Un élément-clé qui illustre cette évolution est le rapport de l'ONU publié récemment sur "L'état de l'insécurité alimentaire dans le monde " (http://www.fao.org/publications/sofi/fr/).

Ce rapport reconnaît maintenant que les fruits et les légumes sont une composante importante d'une alimentation saine, se référant à la recommandation de l'OMS et la FAO pour un apport journalier minimum de $400 \mathrm{~g}$ de fruits et légumes. Mettant l'accent sur les liens avec la santé, il indique clairement qu'en dessous de ce niveau il pourrait y avoir une augmentation du risque de maladies chroniques et qu'une consommation suffisante de fruits et légumes contribue également à prévenir les carences en micronutriments.

Ce rapport indique également que, dans le monde entier, la part des céréales, racines et tubercules diminue sensiblement, tandis que la part des fruits et légumes tend à augmenter, reconnaissant l'impact bénéfique d'une telle évolution pour la santé et la nutrition. Mais il existe des contrastes forts entre les régions. Alors que les apports nutritionnels des fruits et légumes ont progressé sensiblement en Asie, ils demeurent stagnants en Afrique subsaharienne où la part des apports énergétiques alimentaires provient toujours en grande majorité des céréales, racines et tubercules. Dans ce rapport, il est en outre intéressant de noter que dans les pays où les revenus augmentent, l'apport de céréales, racines et tubercules pour la fourniture totale alimentaire par habitant diminue alors que la contribution des aliments d'origine animale et des fruits et légumes augmente sensiblement.

Ces références aux fruits et légumes dans un tel rapport-clé est peuvent être perçues comme le signal positif d'une prise de conscience nouvelle de la communauté internationale quant à la nécessité de les intégrer dans l'agenda général de la sécurité alimentaire où les liens entre agriculture, nutrition et santé sont de plus en plus évidents et nécessaires. On peut toutefois regretter que le rôle des fruits et légumes n'ait pas été repositionné dans une absolue nécessité de diversification des systèmes alimentaires et qu'une telle référence ne figure pas explicitement dans les messages-clés de ce rapport, ce qui lui aurait donné une bien plus grande visibilité.

Dr. Jacky Ganry Directeur scientifique de Fruits 